Яровий В. С.;

Пилипчук Ю. В.;

Троцько Л. Г.;

Цимбал I. В.;

Гетьман А. B.

Науковий центр зв’язку та інформатизації Військового інституту телекомунікацій та інформатизації імені Героїв Крут, Київ

\title{
Підхід до вибору постачальників (виробників) засобів для потреб воснної розвідки
}

Резюме. У статті наведені положення методичного підходу до вибору засобів розвідки та їх постачальників (виробників) для потреб воєнної розвідки. В основу методичного підходу покладений метод рейтингових оцінок. Результатом вибору засобів та їх постачальників (виробників) $\epsilon$ згортка сукупності часткових показників, що характеризують цільове призначення засобів та умови їх постачання до споживачів - відповідних підрозділів воєнної розвідки.

Ключові слова: закупівля засобів розвідки; державні замовники; часткові показники оцінювання; метод рейтингових оцінок.

Постановка проблеми. На сьогодні закупівля засобів розвідки здійснюється відповідно до вимог, що визначені чинними нормативно-правовими актами України [1-3]. У цих документах визначені етапи, процедури та особливості закупівлі продукції, робіт і послуг за державні кошти, в тому числі i засобів розвідки. Однак, на сьогодні, відсутній підхід або методика на основі яких можна здійснювати вибір з-поміж декількох пропозицій на основі визначених критеріїв. Отже розроблення методичного підходу на основі якого можна вибрати найприйнятніший засіб розвідки та його постачальника (виробника) за критерієм “ціна-якість" та 3 урахуванням вимог чинного законодавства України $\epsilon$ актуальним науково-практичним завданням.

Аналіз останніх досліджень i публікацій. Існує низка напрацювань, присвячених питанням оптимізації витрат на виробництво озброєння і військової техніки та вибору постачальників озброєння [4-6]. У цих роботах розроблено ряд методик для вирішення питання оснащення озброєнням військ і підрозділів, однак, проблема вибору засобів розвідки та їх постачальників (виробників) 3-поміж декількох пропозицій за критерієм “ціна-якість” та 3 урахуванням вимог чинного законодавства не розглядалась.

Метою статті $€$ обгрунтування методичного підходу щодо вибору засобів розвідки та їх постачальників для потреб воєнної розвідки.
Викладення основного матеріалу. Під час закупівлі засобів розвідки необхідно враховувати особливості вибору виробників (постачальників) таких засобів [1-3].

Відповідно до обраної процедури закупівлі визначається необхідність проведення оцінювання засобів розвідки та їх постачальників (виробників). У випадку, коли обрана процедура закупівлі не передбачає проведення оцінювання засобів розвідки та їх постачальників (виробників) закупівля здійснюється згідно з [3]. Якщо обрана процедура закупівлі передбачає вибір 3 декількох виробників (постачальників), то для здійснення такого вибору необхідний методичний апарат, за допомогою якого можна було б провести таке оцінювання.

Оскільки сукупність об'єктів, які оцінються під час вибору засобів розвідки та їх постачальників, може бути описана великою кількістю різноманітних за своїм физичним змістом характеристик, то для проведення такого оцінювання доцільно обрати метод рейтингових оцінок. Такий метод передбачає використання математичного апарату, який дає змогу згорнути сукупність різних за своєю сутністю показників до одного узагальненого показника, що буде кількісно визначати ступінь переваги одного об'єкта дослідження над іншими [7].

Застосування методу рейтингових оцінок передбачає низку обмежень і припущень, а саме:

рейтингові дослідження передбачають використання математичного апарату, який дає 
змогу згорнути сукупність різних за своєю сутністю показників до одного узагальненого показника, що буде кількісно визначати ступінь переваги одного об'єкта дослідження над іншими;

для проведення такого оцінювання залучається група експертів; сума вагових коефіцієнтів показників та часткових показників оцінювання має дорівнювати одиниці.

Послідовність дій 3 оцінювання засобів розвідки та постачальників (виробників) цих засобів у разі застосування методу рейтингових оцінок наведена на рис. 1.

\begin{tabular}{|c|c|}
\hline \multicolumn{2}{|c|}{ Перелік засобів розвідки та їх постачальників (виробників) } \\
\hline \multicolumn{2}{|c|}{$\begin{array}{c}\text { Визначення переліку показників, які характеризують засоби розвідки та їх } \\
\text { постачальників (виробників) }\end{array}$} \\
\hline \multicolumn{2}{|c|}{$\begin{array}{c}\text { Визначення вагових коефіцієнтів показників, які характеризують засоби } \\
\text { розвідки та їх постачальників (виробників) }\end{array}$} \\
\hline \multicolumn{2}{|c|}{$\begin{array}{c}\text { Визначення переліку часткових показників, на основі яких розраховується } \\
\text { кожний показник, який характеризує засоби розвідки та їх постачальників } \\
\text { (виробників) }\end{array}$} \\
\hline \multicolumn{2}{|c|}{ Визначення вагових коефіцієнтів часткових показників } \\
\hline \multicolumn{2}{|c|}{ Визначення вимог (потрібних значень) до часткових показників } \\
\hline \multicolumn{2}{|c|}{$\begin{array}{c}\text { Обчислення значення кожного показника шляхом проведення згортки } \\
\text { сукупності часткових показників кожного } 3 \text { них }\end{array}$} \\
\hline $\begin{array}{r}\text { Розрахунок значення рейтингу кожного } \\
\text { (виробника) шляхом згор }\end{array}$ & $\begin{array}{l}\text { засобу розвідки та його постачальника } \\
\text { тки значень їх показників }\end{array}$ \\
\hline
\end{tabular}

Як видно 3 рис. 1 проведення такого оцінювання складається 3 послідовності етапів. Одним 3 основних етапів є визначення показників, що характеризують об'єкти, які оцінюються.

3 огляду на завдання, які вирішуються під час вибору засобів розвідки та їх постачальників (виробників), та вимоги чинного законодавства засоби розвідки та їхні постачальники (виробники) можуть оцінюватись за такими трьома показниками $D_{i}$ :

$D_{1}-$ показник, який характеризує якість засобу розвідки;

$D_{2}$ - показник, який визначає спроможність постачальника (виробника) постачати (виробляти) засоби розвідки;

$D_{3}-$ показник, що відображає ціну засобу розвідки.

Тоді узагальнене рейтингове оцінювання засобу розвідки та його постачальника (виробника) здійснюватиметься за формулою [7]

$$
R_{f}=\sum_{i=1}^{3} a_{i} D_{f i}
$$

де $R_{f}$ - результат рейтингового оцінювання засобу розвідки, який пропонується $f$-м постачальником (виробником); $a_{i}$ - ваговий коефіцієнт $i$-го показника.

Для визначення значень вагових коефіцієнтів показників відповідно до [8] авторами було проведено експертне опитування, щодо визначення вагових коефіцієнтів показників, які характеризують засоби розвідки та їх постачальників (виробників). За результатами обробки проведеного експертного оцінювання було визначено значення вагових коефіцієнтів показників, які характеризують засоби розвідки та їх постачальників (табл. 1).

Значення показника, який характеризує якість засобу розвідки визначається низкою часткових показників, які умовно можна розділити на дві групи: часткові показники, які кількісно характеризують здатність засобу розвідки виконувати свої завдання за призначенням i часткові показники пристосованості засобів розвідки до експлуатації та збереженню працездатності.

Перелік часткових показників, за допомогою яких оцінюється здатність засобу розвідки виконувати свої завдання за призначенням, визначається залежно від специфічних особливостей та призначення конкретного виробу. Такий перелік визначається, як правило, з основних тактикотехнічних характеристик засобу розвідки. До 
таких тактико-технічних характеристик можна віднести [9, 10]: масо-габаритні характеристики; дальність дії; розрізнювальна здатність; точність виміру певних параметрів; споживана потужність; робітний час (швидкодія); обсяг пам’ яті тощо.

Таблиця 1

Значення вагових коефіціснтів показників, які характеризують засоби розвідки та їх постачальників (виробників)

\begin{tabular}{|l|c|}
\hline \multicolumn{1}{|c|}{ Назва вагового коефіцієнта } & Значення \\
\hline $\begin{array}{l}\text { Ваговий коефіцієнт показника, який характеризує якість засобу розвідки (засобу } \\
\text { подвійного призначення) }\end{array}$ & 0,39 \\
\hline $\begin{array}{l}\text { Ваговий коефіцієнт показника, який визначає спроможність постачальника (виробника) } \\
\text { постачати (виробляти) засоби розвідки (засоби подвійного призначення) }\end{array}$ & 0,27 \\
\hline $\begin{array}{l}\text { Ваговий коефіцієнт показника, який відображає ціну засобу розвідки (засобу } \\
\text { подвійного призначення) }\end{array}$ & 0,34 \\
\hline
\end{tabular}

Конкретна сукупність
технічних тактико-
оцінюватись, обактеристик,
типом засобу розвідки і визначається на етапі
підготовки вихідних даних для проведення
такого оцінювання.

До часткових показників, які відображають пристосованість засобу розвідки до експлуатації і збереженню працездатності, як правило, можна віднести [9, 10]: умови експлуатації (мінімальна та максимальна температура навколишнього середовища в якій забезпечується нормальна робота технічного засобу, вологість повітря тощо); час напрацювання на відмову; середній час безперервної роботи; технічний ресурс; ремонтопридатність тощо.

Тоді значення показника, який характеризує якість засобу розвідки, визначається за формулою [4]

$$
D_{1}=\sqrt{\min _{j=1, r}\left[U_{j}\left(1-a_{j}\right)\right] \sum_{j=1}^{r} U_{j} a_{j}},
$$

де $U_{j}$-співвідношення $j$-го часткового показника, який характеризує якість засобу розвідки;

$a_{j}$ - ваговий коефіцієнт j-го часткового показника, який характеризує якість засобу розвідки;

r-кількість часткових показників, які характеризують якість засобу розвідки. Співвідношення $j$-го часткового показника, який характеризує якість засобу розвідки, прямої залежності (коли найкращим $\epsilon$ максимальне значення) розраховується за формулою [11]

$$
U_{j}=W_{j} / W_{j n o m p ~},
$$

де $W_{j}$ - значення $j$-го часткового показника, що пропонує постачальник (виробник);
$W_{\text {jпотр }}$ - значення $j$-го часткового показника, що висуває замовник або найбільше можливе значення із запропонованих постачальником (виробником).

Співвідношення $j$-го часткового показника зворотної залежності (коли найкращим $\epsilon$ мінімальне значення) визначається за формулою [11]

$$
U_{j}=W_{j n o m p} / W_{j},
$$

де $W_{\text {jпотр }}$ - значення $j$-го часткового показника, що висуває замовник або найменше можливе значення із запропонованих постачальником (виробником).

Визначення вимог (потрібних значень) до часткових показників, які характеризують якість засобу розвідки та їх вагових коефіцієнтів має здійснюватись органом (підрозділом) воєнної розвідки, в інтересах якого здійснюється закупівля.

Показник, що відображає спроможність підприємства постачати (виробляти) засоби розвідки характеризується низкою часткових показників. До таких часткових показників можна віднести [9]: досвід роботи підприємства на ринку; стан виробничої бази; виробничі потужності; наявність та терміни гарантії та післягарантійного обслуговування; віддаленість постачальника (виробника) тощо.

Визначення значень часткових показників, які характеризують спроможність підприємства постачати (виробляти) засоби розвідки, доцільно здійснювати за 10-бальною шкалою. До того ж значення кожного часткового показника, яке висувається замовником до постачальника (виробника) приймається рівним 10. Тоді згортка групи часткових показників, що відображають спроможність підприємства постачати (виробляти) засоби розвідки розраховується так [7]: 


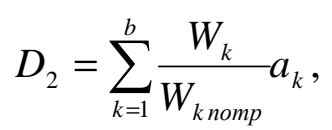

де $W_{k}$ - значення за обраною шкалою щодо оцінки $k$-го часткового показника, що відображає спроможність підприємства постачати (виробляти) засоби розвідки;

$$
\begin{gathered}
W_{k \text { nоmp }} \text { - максимальне значення } k \text {-го } \\
\text { часткового показника відповідно до }
\end{gathered}
$$
обраної шкали;

$a_{k}$ - ваговий коефіцієнт $k$-го часткового показника, що відображає спроможність підприємства постачати (виробляти) засоби розвідки;

$b$ - кількість часткових показників, за якими оцінюється спроможність підприємства постачати (виробляти) засоби розвідки.

Вагові коефіцієнти часткових показників, що відображають спроможність підприємства постачати (виробляти) засоби розвідки визначаються аналогічно до вагових коефіцієнтів показників, які характеризують засоби розвідки та їх постачальників (виробників).

До часткових показників, що відображають ціну засобу розвідки можна віднести такі: ціна засобу розвідки; ціна гарантійного обслуговування тощо.

Визначення значень часткових показників, що відображають ціну засобу розвідки, здійснюється за співвідношенням мінімально можливої ринкової ціни на засіб розвідки (ціни гарантійного обслуговування) до ціни на засіб, що оцінюється (ціни гарантійного обслуговування, що надає виробник (постачальник)). Тоді згортка часткових показників, що відображають ціну засобу розвідки розраховується так [7]:

$$
D_{3}=\sum_{p=1}^{d} \frac{W_{p \min }}{W_{p}} \times a_{p},
$$

де $W_{p \min }$ - значення $\quad p$-го часткового

показника, що відображає найнижчу ціну засобу розвідки, яку пропонує постачальник (виробник);

$W_{p}$ - значення $p$-го часткового показника, що відображає ціну засобу розвідки;

$\alpha_{p}$ - ваговий коефіцієнт $p$-го часткового показника, що відображає ціну засобу розвідки;

$D$ - кількість часткових показників, що відображають ціну засобу розвідки.

Вагові коефіцієнти часткових показників, що відображають ціну засобу розвідки визначаються аналогічно до вагових коефіцієнтів показників.

Після проведення розрахунків, що передбачені методом рейтингових оцінок, визначається засіб розвідки та його виробник (постачальник) 3 найвищим показником рейтингу шляхом співставлення визначених рейтингів. На основі отриманих значень приймається рішення щодо вибору засобу розвідки та його постачальника (виробника).

Висновок. Запропонований методичний підхід щодо вибору засобів розвідки та їх постачальників (виробників) в інтересах воєнної розвідки. Такий методичний підхід дає змогу згорнути сукупність різних за своєю сутністю показників до одного узагальненого показника, що кількісно визначатиме ступінь переваги одного об'єкта дослідження над іншими. На основі такого підходу можна визначити кращий засіб розвідки та його виробника (постачальника) за обраними показниками, такими, наприклад, як якість засобу розвідки та його ціна.

Подальшим напрямом досліджень може бути визначення вимог (потрібних значень) до часткових показників, які характеризують якість конкретних засобів розвідки та їх вагових коефіцієнтів.

\section{СПИСОК ВИКОРИСТАНОЇ ЛІТЕРАТУРИ}

1. Питання державного оборонного замовлення / Постанова Кабінету Міністрів України від 27.04.2011 року № 464. - Офіц. вид. - К.: Офіційний вісник України, 2011, № 34, ст. 1402.

2. Про державне оборонне замовлення / Закон України. - К.: Відомості Верховної Ради України 1999, № 17, ст. 111.

3. Про здійснення державних закупівель / Закон України. - К.: Відомості Верховної Ради України, 2010, № 33, ст. 471.

4. Бывших Д. М. Методический подход к обоснованию приоритетных направлений сосредоточения усилий в развитии многофункциональной организационнотехнической системы военного назначения [Електронний ресурс] / Д. М. Бывших, В. А. Орлов, Ю. Н. Ярыгин // Вооружение и экономика. Электронный научный журнал. - 2014.

№ 3 (28). - С. 51-62. - Режим доступу до журн.: http://www.viek.ru.

5. Короленко В. В. Методика рационального распределения заказов на материальные ресурсы при планировании поставок в системе интегрированной логистической поддержки эксплуатации авиационной техники военного назначения [Електронний ресурс] / В. В. Короленко, Н. М. Лазников // Вооружение и экономика. Электронный научный журнал. - 
2014. - № 2 (27). - С. 85-97. - Режим доступу до журн.: http://www.viek.ru.

6. Иванцов Д. В. Оценка производственных возможностей предприятий обороннопромышленного комплекса в интересах формирования государственного оборонного заказа в части закупок вооружения, военной и специальной техники [Електронний ресурс] / Д. В. Иванцов // Вооружение и экономика. Электронный научный журнал. - 2014. - № 2 (27). - С. 104-115. - Режим доступу до журн.: http://www.viek.ru.

7. Дудак Н. С. Сборник методических указаний в двенадцати частях. Часть 1. Качество машиностроительных изделий / Дудак Н. С. Павлодар: ПГУ им. С. Торайгырова, 2007. $228 \mathrm{c}$.
8. Шошин П. Б. Метод экспертных оценок / Шошин П. Б. - М.: 1987. - 80 с.

9. Демидов Б. А. Теория и методы военно-научных исследований вооружения и военной техники / Демидов Б.А. - Харьков: Издание академии, 1990. - 557 c.

10. Гриб Д. А. Системно-концептуальні основи і елементи методології формування оперативнотактичних i тактико-технічних вимог, що пред'являються до перспективних зразків озброєння і військової, що модернізуються / Д. А. Гриб, . О. Демідов, М. В. Науменко // Системи озброєння і військова техніка. - 2009 № 2 (18). - C. 65-73.

11. Самохвалов Ю. Я. Організаційно-методичні аспекти науково-технічної експертизи / Ю. Я. Самохвалов, О. І. Бурба. - К.: ТОВ “Три К”, 2013. - $108 \mathrm{c}$.

Стаття надійшла до редакційної колегії 18.10.2018

Яровой В. С.;

Пилипчук Ю. В.;

Троцько Л. Г.;

Цимбал І. В.;

Гетьман А. В.

Научный центр связи и информатизации Военного института телекоммуникаций и информатизации имени Героев Крут, Киев

\section{Подход к выбору поставщиков (изготовителей) средств для нужд военной разведки}

Резюме. В статье представлены положения методического подхода к выбору средств разведки и их поставщиков (изготовителей) средств для нужд военной разведки. В основу методического подхода положен метод рейтинговых оценок. Результатом выбора средств и их поставщиков (изготовителей) есть объединение совокупности частичных показателей, которые характеризуют целевое назначение средств и условия их поставки потребителям - соответствующим подразделениям военной разведки.

Ключевые слова: закупка средств разведки; государственные заказчики; частичные показатели оценки; метод рейтинговых оценок.

\section{Yarovyi; \\ Y. Pylypchuk; \\ L. Trotsko; \\ I. Tsymbal; \\ A. Hetman}

Scientific Center for Communication and Informatization Military Institute of Telecommunications and Information Technologies the name of the Heroes of Kruty, Kyiv

Approach to selection of suppliers (manufacturers) of tools for malignant requirements

Resume. The article outlines the methodological approach to the choice of intelligence agents and their suppliers (producers) for the needs of military intelligence. The methodological approach is based on the method of rating assessments. The result of the choice of means and their suppliers (producers) is the convolution of a set of partial indicators that characterize the intended use of facilities and the conditions for their delivery to consumers, the relevant units of military intelligence.

Keywords: procurement of intelligence; government customers; partial evaluation indicators; method of rating assessments. 